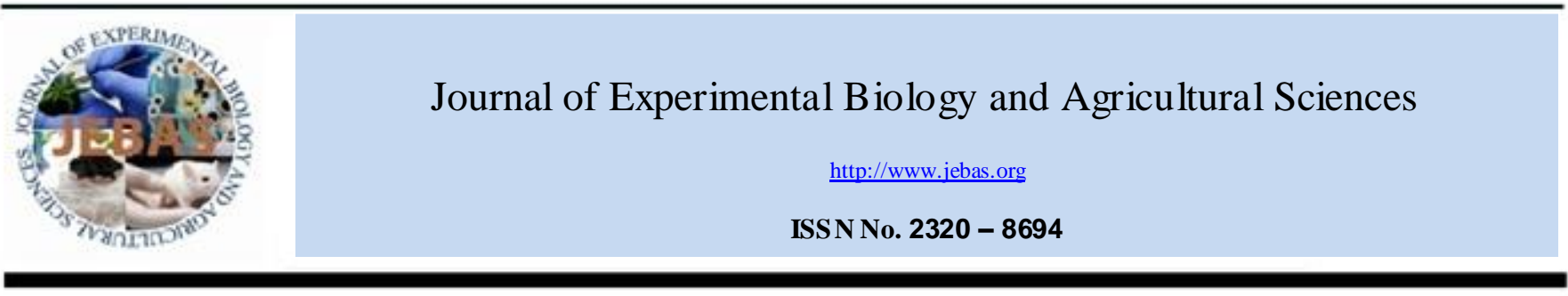

\title{
EFFECT OF CONSOLIDATE APPLICATION OF ORGANIC AND CHEMICAL FERTILIZERS ON THE PHYSICAL AND CHEMICAL TRAITS OF SOIL AND QUALITATIVE INDEX OF CORN (Zea mays L) PLANTS
}

\author{
Esmaeil Namazi ${ }^{1, *}$, Ebrahim Fatahi Nejad ${ }^{2}$ and Shahram Lak ${ }^{1}$ \\ ${ }^{1}$ Departments of Agronomic Ahvaz Branch, Islamic Azad University Ahvaz, Iran \\ ${ }^{2}$ Departments of Soil Sciences, Behbahan Branch, Islamic Azad University, Behbahan, Iran \\ Received - February 11, 2015; Revision - February 25, 2015; Accepted - June 07, 2015 \\ Available Online - June 19, 2015
}

DOI: http://dx.doi.org/10.18006/2015.3(3).253.260

KEYWORDS
Corn
Protein
Oil
Nitrogen fertilizer
Vermicompost

\begin{abstract}
ABSTRAC T
Present study was conducted to analysis the effect of Vermicompost and chemical nitrogen fertilizer on physical and chemical traits of soil's and qualitative indexes of corn plant. A factorial test with complete random block designs with 4 repetitions was conducted in the year of 2012. Three doses of chemical nitrogen fertilizers viz $50,75 \& 100 \mathrm{~kg} /$ hectare and two level of vermicompost viz 5 \& 10 tons/hectare were used either individually or in combination with each others. Results of the study revealed that the use of Vermicompost and chemical nitrogen fertilizer caused a significant increase in the percentage of seed oil contents. At individual application of chemical nitrogen fertilizer highest increment in seed oil content was reported at $100 \mathrm{~kg} /$ hectare application, while in combination it was reported higher in the combination of $75 \mathrm{~kg} /$ hectare chemical Nitrogen fertilizer and 10 ton/hectare vermicompost. The least effective treatment of was the combination of $100 \mathrm{~kg} /$ hectare chemical nitrogen fertilizer and 10 tons/hectare vermicompost combination. The most bulk gravity and real gravity is due to the treatment of Nitrogen chemical fertilizer at $50 \mathrm{~kg} /$ hectare of soil test and without the use of vermicompost and the least bulk and real gravity of soil belong to the treatment of Nitrogen chemical fertilizer at the amount of $100 \mathrm{~kg} / \mathrm{hectare}$ of soil test and use of vermicompost at the amount of 10 tons in hectare.
\end{abstract}

* Corresponding author

E-mail: esmaeilnamazi@y ahoo.com (Esmaeil Namazi)

Peer review under responsibility of Journal of Experimental Biology and Agricultural Sciences.

Production and Hosting by Horizon Publisher (www.my-

vision.webs.com/horizon.html).

All rights reserved.
All the article published by Journal of Experimental Biology and Agricultural Sciences is licensed under a Creative Commons Attribution-NonCommercial 4.0 International License Based on a work at www.jebas.org.

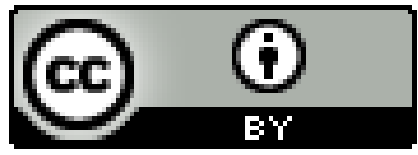




\section{Introduction}

Plants obtained maximum essential elements which required for their growth from the soil. Total thirteen essential elements are required for the normal growth of plant; among these nitrogen, phosphorus, and potassium are the macronutrient which removed from the soil most rapidly. Therefore, many commercial plant fertilizers supply these three essential elements. Nitrogen fertilizers are undoubtedly an essential and benefited resource for agric ulture and recently its consumption increased exponentially throughout the world. Nitrogen can supplied in the form of ammonia $\left(\mathrm{NH}_{3}\right)$, diammonium phosphate $\left(\left(\mathrm{NH}_{4}\right) 2 \mathrm{HPO}_{4}\right)$, ammonium nitrate $\left(\mathrm{NH}_{4} \mathrm{NO}_{3}\right)$, ammonium sulfate $\left(\left(\mathrm{NH}_{4}\right)_{2} \mathrm{SO}_{4}\right)$, calcium cyanamide $\left(\mathrm{CaCN}_{2}\right)$, calcium nitrate $\left(\mathrm{Ca}\left(\mathrm{NO}_{3}\right)_{2}\right)$, sodium nitrate $\left(\mathrm{NaNO}_{3}\right)$, and urea $\left(\mathrm{N}_{2} \mathrm{H}_{4} \mathrm{CO}\right)$. On the one hand, nitrogen is necessary for crop growth and development while on the other hand, applying nitrogen in excess has been linked to water and air pollution, depletion of the ozone layer, climate change and numerous human health concerns Furthermore, fertilization may affect the accumulation of heavy metals in soil and plant system. Plants absorb the fertilizers through the soil; they can enter the food chain. Thus, fertilization leads to water, soil and air pollution (Galloway et al., 2003; Savci, 2012; Rosenstock et al., 2013). Excess use of these chemical fertilizers can be minimized by combining the organic compost or fertilizers.

Vermicompost is the product of semi aerobic processing (about $80 \%$ moisture) which is developed by annular red earthworm (Esinia foetida) (Garg et al 2006:paramonik et al 2007). Chemical analysis of this suggest that this organic fertilizer have various enzymes, growth hormones and a high amount of nutritious elements which are available for the plants and affective in increasing the functioning of different crops (Riggy, 2003; Roesty et al., 2006; Garg et al., 2006; Pramanik et al., 2007). These vermicompost have capacity to hold the nutritious elements of soil and increase in the biological functioning which induced the soil construction. Furthermore, vermicompost increase the microbial activity in the soil which affect the soil functioning and water holding capacity of the soil. It has been also reported that soil with earthworm increased the aeration of the soil and this type of soil shows 8 30 percent higher aeration than the soil without vermicompost. Furthermore, present of these organism increasing the water penetration and holding capacity of the soil and such type of soil shows 2-10 times higher water penetration (Rejali \& Khavazi 2001; Arancon et al., 2004). Use of Vermicompost affects the quantitative and qualitative characteristics of plants and cause healthy environment. Therefore use of vermicompost in stable agriculture not only increases the population of useful microorganisms but also added the nutritious elements such as Nitrogen, phosphor magnesium and potassium in the soil which improve the growth and activity of the crops (Kumar \& Singh, 2001). Present study has been undertaken for finding out the effect of individual or combined application of chemical nitrogen fertilizers and vermicompost on the quantitative and qualitative characteristic of soil and corn plant.

\section{Materials and Methods}

This study has been conducted in the year 2012 in a farm located in the city of Behbahan in Khozistan province. The test was conducted in factorial in complete block design randomly in 4 repetitions. Three level of Nitrogen chemical fertilizer i.e 50,75 and $100 \mathrm{Kg} /$ hectare and two levels of organic vermicompost i.e. 5 and 10 tons per hectare were imposed for the present study. To review and analyze the soil chemical traits after the completion of corn harvesting, the surface soil of cultivated plots were collected from the depth of $30 \mathrm{~cm}$ of each plot. All the collected samples were mixed together and a representative sample was separated. Amount of the absorbable phosphor was measured by the Oleson method while the amount of absorbable potassium was measured by the photometric film instrument as described by Ehyaei \& Behbehanizadeh (1993). Furthermore the amount of seed protein was measured by the Kejeldal method while for measuring percentage of seed oil Sokseleh method has been used (Hosseini, 1994). Variances of analysis for all the traits were calculated by the use of "Mastatc software and comparing the average of treatments Danken multi domain method at the possible level of $5 \%$.

\section{Results and Discussions}

Results of the study revealed the effect of chemical fertilizers and vermicompost on the various traits of soil and corn sees. Furthermore, for various soils traits these combinations shows superiority over the individual application of chemical fertilizers or vermicompost while for the seed characteristics, these combination have slightly negative effect than the individual application of chemical nitrogen fertilizer and vermicompost.

\subsection{Percentage of seed's oil}

Results of variance analysis showed that the effect of vermicompost application at the level of $5 \%$ is meaningful while the effect of excess use of Nitrogen chemical fertilizer and the effect of mutual treatment is meaningless. (table1).

At individual application level use of $75 \mathrm{Kg} /$ hect are Nitrogen in soil showed maximum percentage of seed oil production while the least seed oil content was reported at the $100 \%$ chemical Nitrogen fertilizer (table 2). Results of the interaction show that the combination of $100 \mathrm{Kg} /$ hectare chemical nitrogen fertilizer without vermicompost shows maximum percentage of oil content $(10.80 \%)$ while the least amount of oil content (8.13) was reported from the combination of $100 \mathrm{Kg} / \mathrm{hectare}$ Nitrogen chemical fertilizer treatment with 10 tons of vermicompost. 
Table 1 Effect of chemical fertilizers and vermicompost on the discussed variance analysis traits

\begin{tabular}{|lccccccc|}
\hline Changes resources & $\begin{array}{c}\text { degree of } \\
\text { freedom }\end{array}$ & $\begin{array}{c}\text { seed's oil } \\
\text { percentage }\end{array}$ & $\begin{array}{c}\text { seed's } \\
\text { protein } \\
\text { percentage }\end{array}$ & $\begin{array}{c}\text { soil } \\
\text { phosphor } \\
\text { absorption }\end{array}$ & $\begin{array}{c}\text { soil } \\
\text { potassium } \\
\text { absorption }\end{array}$ & $\begin{array}{c}\text { bulk } \\
\text { gravity }\end{array}$ & $\begin{array}{c}\text { real } \\
\text { gravity }\end{array}$ \\
Repetition & 3 & $5.949^{*}$ & $0.624^{\text {ns }}$ & $0.250^{\text {ns }}$ & $2.769^{\text {ns }}$ & $0.016^{* *}$ & $0.001^{*}$ \\
\hline Nitrogen & 2 & $3.712^{\text {ns }}$ & $1.234^{*}$ & $63.861^{* *}$ & $73^{* *}$ & $0.033^{* *}$ & $0.002^{*}$ \\
\hline Vermicompost & 2 & $4.028^{*}$ & $1.942^{* *}$ & $912.528^{* *}$ & $1705.58^{* *}$ & $0.259^{* *}$ & $0.051^{* *}$ \\
\hline Nitrogen*vermicompost & 4 & $2.968^{\mathrm{ns}}$ & $0.474^{\mathrm{ns}}$ & $3.944^{* *}$ & $160.58^{* *}$ & $0.002^{\mathrm{ns}}$ & $0.001^{\mathrm{ns}}$ \\
\hline Error & 24 & 1.506 & 0.252 & 0.875 & 0.956 & 0.002 & 0.0001 \\
\hline Variation coefficient & - & 12.73 & 5.82 & 6.62 & 0.53 & 3.05 & 0.69 \\
\hline
\end{tabular}

** and $n$ s are respectably meaningful at the possible level of $5 \%, 1 \%$ and no difference are meaningful

Table 2 Effect of individual application of the chemical nitrogen fertilizers and vermicompost on the soil and maiz seed characteristics.

\begin{tabular}{|c|c|c|c|c|c|c|}
\hline Treatments & $\begin{array}{l}\text { Seed's oil } \\
\text { Percentage }\end{array}$ & $\begin{array}{l}\text { Seed's protein } \\
\text { Percentage }\end{array}$ & $\begin{array}{c}\text { Absorbable } \\
\text { Phosphor in Soil } \\
\text { (PPM) }\end{array}$ & $\begin{array}{c}\text { Absorbable } \\
\text { Potassium in Soil } \\
\text { (PPM) }\end{array}$ & $\begin{array}{c}\text { Bulk } \\
\text { Gravity } \\
\left(\mathrm{g} / \mathrm{cm}^{3}\right)\end{array}$ & $\begin{array}{c}\text { Real } \\
\text { Gravity } \\
\left(\mathrm{g} / \mathrm{cm}^{3}\right)\end{array}$ \\
\hline \multicolumn{7}{|c|}{ Nitrogen( Kg /hectare) } \\
\hline $50 \mathrm{Kg} / \mathrm{ha}$ & $9.63^{\mathrm{a}}$ & $8.26^{\mathrm{a}}$ & $13.83^{\mathrm{b}}$ & $186.58^{\mathrm{a}}$ & $1.40^{\mathrm{a}}$ & $2.57^{\mathrm{b}}$ \\
\hline $75 \mathrm{Kg} / \mathrm{ha}$ & $10.19^{\mathrm{b}}$ & $8.79^{\mathrm{a}}$ & $16.58^{\mathrm{a}}$ & $182.08^{\mathrm{b}}$ & $1.44^{\mathrm{a}}$ & $2.59^{\mathrm{a}}$ \\
\hline $100 \mathrm{Kg} / \mathrm{ha}$ & $9.08^{\mathrm{a}}$ & $8.84^{\mathrm{a}}$ & $12.00^{\mathrm{b}}$ & $182.58^{\mathrm{b}}$ & $1.50^{\mathrm{a}}$ & $2.59^{\mathrm{a}}$ \\
\hline \multicolumn{7}{|c|}{ Vermicompost (ton/hectare) } \\
\hline Check & $10.30^{\mathrm{a}}$ & $9.08^{\mathrm{a}}$ & $4.16^{\mathrm{c}}$ & $170.66^{\mathrm{c}}$ & $1.59^{\mathrm{a}}$ & $2.66^{\mathrm{a}}$ \\
\hline 5 & $9.36^{\mathrm{b}}$ & $8.51^{\mathrm{b}}$ & $17.91^{\mathrm{b}}$ & $194.00^{\mathrm{a}}$ & $1.45^{\mathrm{b}}$ & $2.56^{\mathrm{b}}$ \\
\hline 10 & $9.25^{\mathrm{b}}$ & $8.30^{\mathrm{b}}$ & $20.33^{\mathrm{a}}$ & $186.58^{\mathrm{b}}$ & $1.30^{\mathrm{c}}$ & $2.53^{\mathrm{c}}$ \\
\hline
\end{tabular}

Averages with common letters in each column don't have significant differences at the levels of 1 and 5 percent according to the Donken multi domain test

In general with increase the dose of chemical nitrogen fertilizer and vermicompost the percentage of seed oil production decreases it shows a negative correlation between percentage of seed oil and nitrogen use. Finding of the present study are in accordance with the findings of Khaliq (2004) those have reported a reduction in the percentage of seed oil production with increasing the dose of nitrogen fertilizer availability for the plant, this may be because of negative correlation between the percentage seed oil and percentage seeds' protein. Furthermore, similar type of findings was report by Mojiery \& Arzani (2003), a negative relation between the amount of nitrogen fertilizer used and percentage of sunflower's seed's oil production and the most percentage of seed's oil belong to witness treatment with $46.6 \%$, and the least production belong to 225 kilograms nitrogen treat ment with $40.8 \%$.

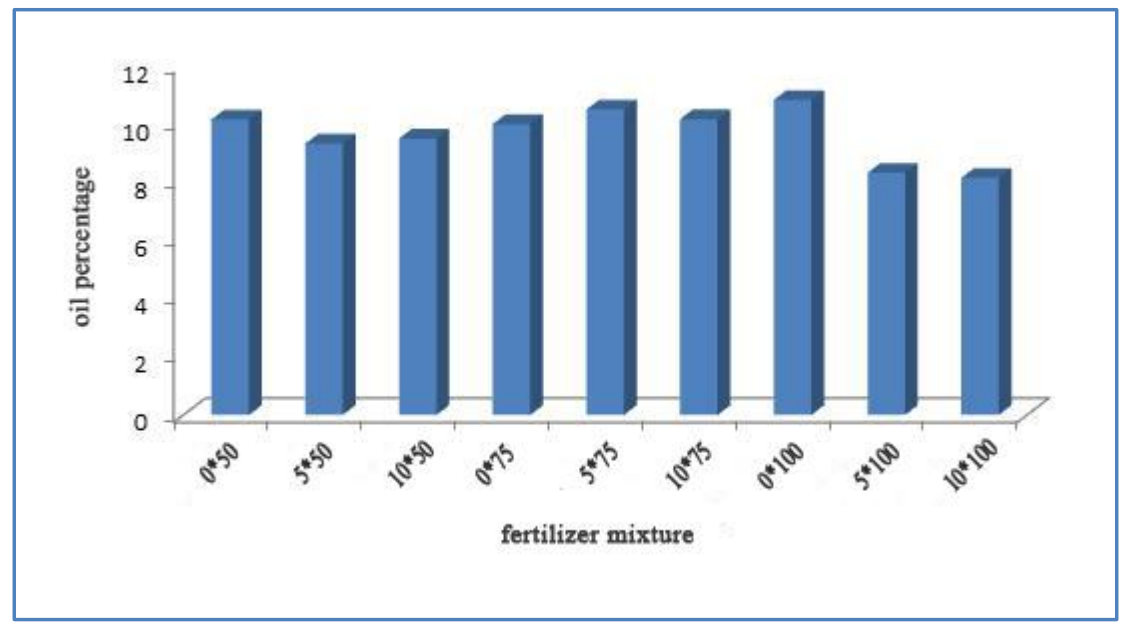

Figure 1 Effect of combined application of vermicompost and nitrogen fertilizer on percentage of seed's oil. 


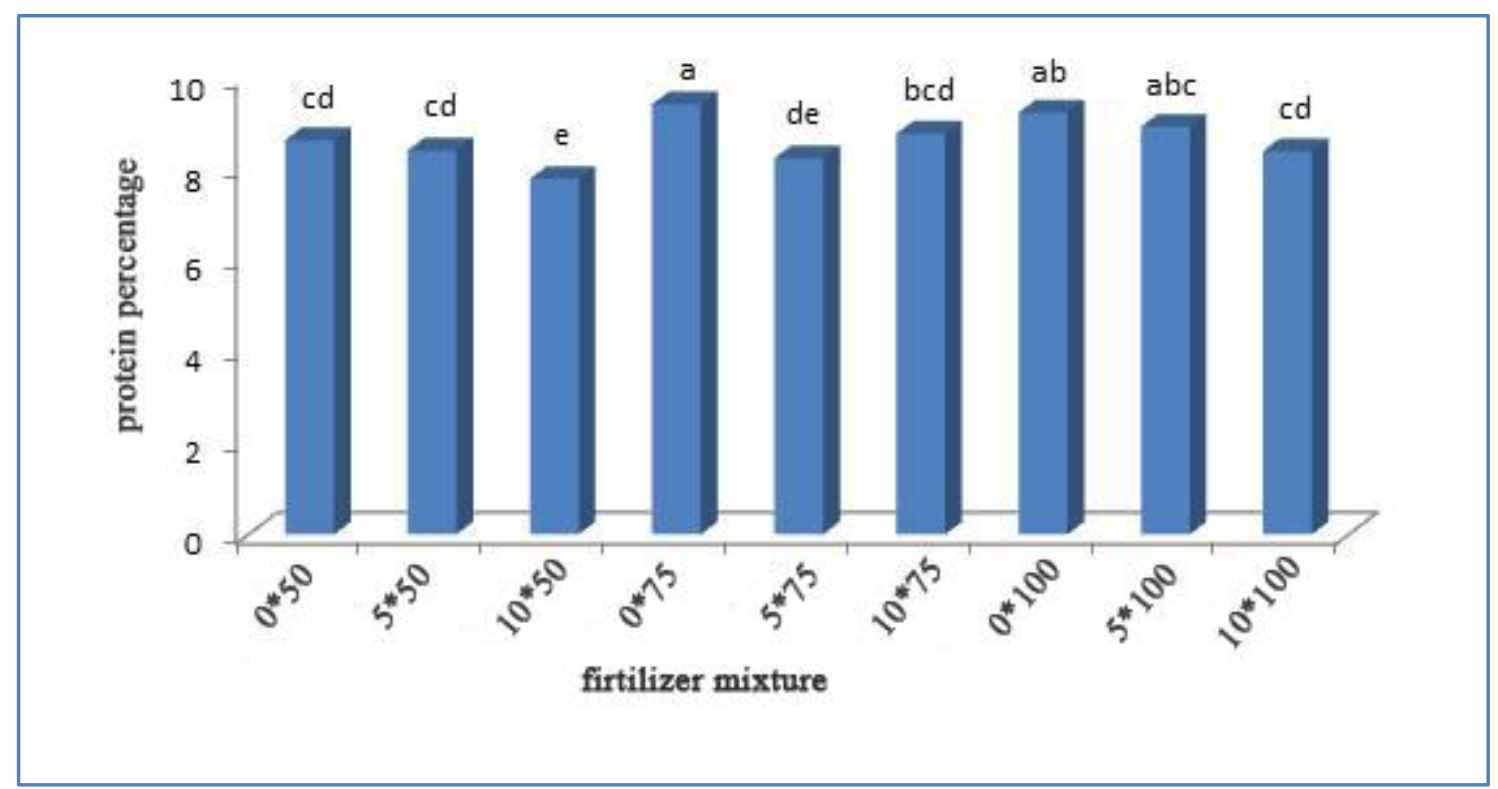

Figure 2 Combined Effects of vermicompost and chemical nitrogen fertilizer on percentage of seed's protein.

\subsection{Effect of combination on the seed's protein:}

Variance of analysis results showed that there is a meaningful effect of chemical nitrogen fertilizer at the possible level of $5 \%$ on the percentage of corn protein. Furthermore, the effect of vermicompost at the possible level of $1 \%$ is meaningful and the effect of the interaction of both treatments on the percentage of seed's protein is non-meaningful (Table 1). Application of chemical nitrogen fertilizer at a known amount increases the amount of nitrogen transformation from the growing part into seed in comparison with hydrocarbons and cause s increase in the density of seed's nitrogen and percentage of protein. As shown in table 2 a non significant difference was reported between the $75 \mathrm{Kg} /$ hectare and $100 \mathrm{Kg} /$ hectare nitrogen level. The reason for high seed's protein at the application of nitrogen can be due to faster absorption of nitrogen and increase of nitrogen density in the aerobic organisms and therefore more transfer of it into seed. Ayub et al. (2002) reported that with increase the nitrogen, concentration quality of corn seed also increases which is due to increase in the raw protein and reduction in the fiber, on the other hand with increasing the amount of nitrogen from 75 $\mathrm{Kg} /$ hectare to $100 \mathrm{Kg} / \mathrm{hectare}$, the amount of protein in the plant increases a little and this is because the high amount of nitrogen which a considerable amount of nitrogen is collecting in non-cultivable parts of plant instead of transforming into amino acids or proteins in the form of nitrogen ions.

Like seed oil content here also individual application of the chemical nitrogen fertilizer shows the superiority over the combined application of the nitrogen fertilizer and vermicompost. The highest protein content was reported from the application of $75 \mathrm{Kg} /$ hectare and it was immediately followed by the application of $100 \mathrm{Kg} / \mathrm{hectare} \& 50 \mathrm{Kg} / \mathrm{hectare}$ chemical nitrogen without vermicompost. Ayub et al. (2002) reported a negative correlation in seed protein contents between the combination of chemical nitrogen fertilizers and vermicompost.

\subsection{Absorbable Phosphor in the soil}

Considering the results obtained from the effect of chemical nitrogen fertilizer and vermicompost on the availability of the absorbable phosphor a significant difference was reported between various treatments (Table 1). The method of increasing the absorbable phosphor has been shown in the table 2 and this value increased with increasing the doses of vermicompost (table 2). Results of the study revealed a statistically significant difference between the treatment consisting 5 and 10 tons/hectare of vermicompost and the highest value of absorbable phosphorus was reported from the treatment containing 10 ton/hectare vermicompost (20.33 PPM). This treatment was immediately followed by individually application of the $100 \mathrm{Kg} /$ hectare Nitrogen fertilizers. Among various treatment tested the least amount of absorbable phosphor (4.16 milligrams in a kilo) has been obtained in the treatment without application of vermicompost. According to Balyan et al. (2008) vermicompost are the richest source of phosphorus and it has the capacity to increase the absorbable phosphorus in soil. The other reason can be low organic material in the soil due to the treatments, since low organic material cause the phosphor in the soil to mix with the soil colloids and goes out of the reach of the plant (Roesty et al., 2006). 


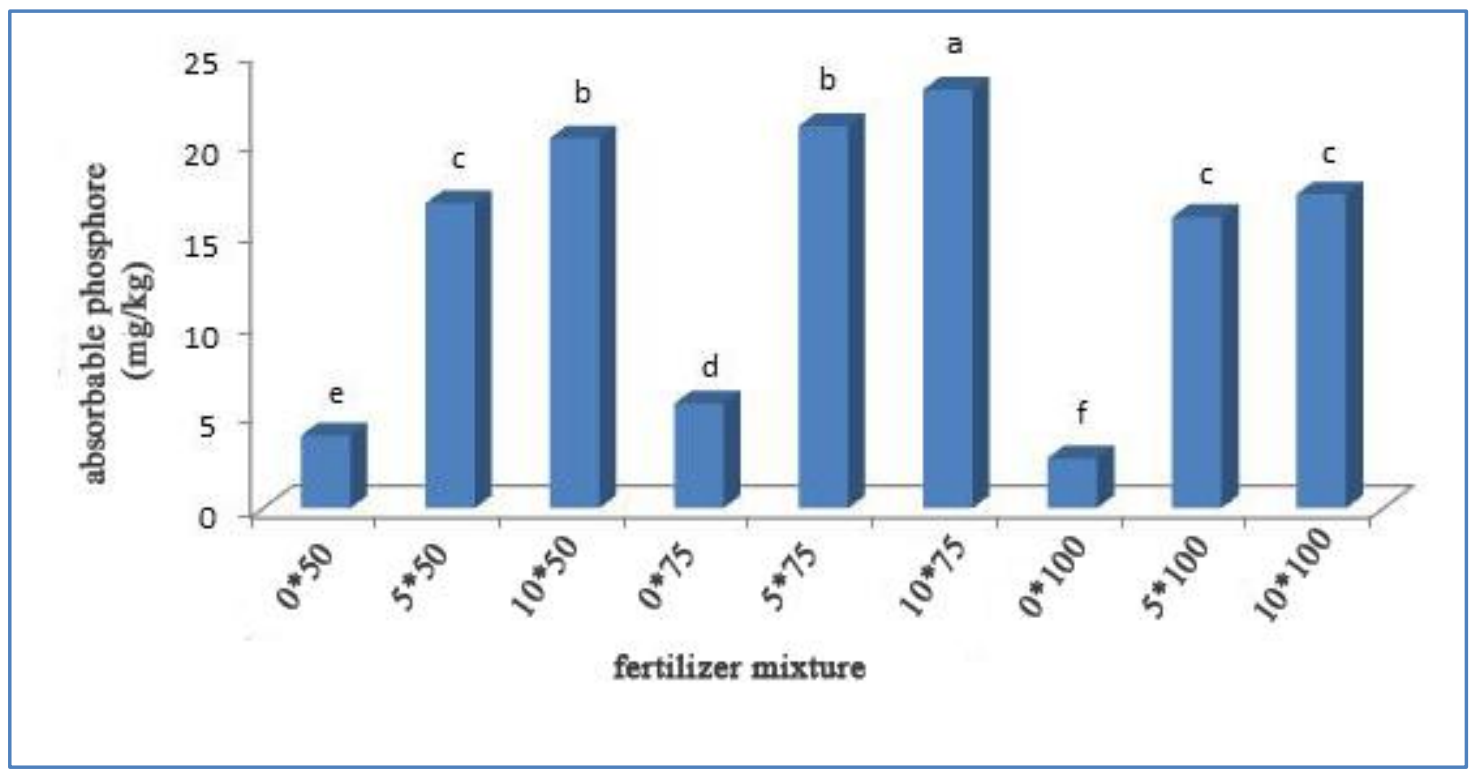

Figure 3 Combined effects of vermicompost and nitrogen chemical fertilizer on the absorbable phosphor in the soil.

Hence, vermicompost increased the capacity of soil phosphor absorption, therefore application of vermicompost causes increase in the soil phosphor since the use of vermicompost at the mentioned levels is not stable on the soil colloids which are due to differences in the $\mathrm{pH}$, the solution phosphor and therefore phosphor absorbable in the soil increases (Anwar et al., 2005).

In combination, higher doses of vermicompost and Nitrogen show maximum absorbable phosphorus in the soil except for the treatment containing combination of 10 tons/hectare vermicompost and $100 \mathrm{Kg} /$ hectare Nitrogen. The highest amount of absorbable phosphorus was reported from the combination of 10 tons/hectare vermicompost and 75
$\mathrm{Kg} /$ hectare Nitrogen. Similar type of results was reported by the Anwar et al. (2005).

\subsection{Presence of absorbable Potassium in the soil}

Potassium has positive effect on the improvement of the rate of photosynthesis, synthesis of NADPH, ATP adjustment of opening and closing of stomatal apertures and decrease in the plant's transpiration in the process of plant's photo synthesis and cause increase in the in the synthesis of protein and speed in the transferring of assimilation in the seed. Considering the variance results of nitrogen chemical fertilizer and vermicompost affects the absorbable potassium in the soil at the possible level of $1 \%$ was meaningf ul (table 1 ).

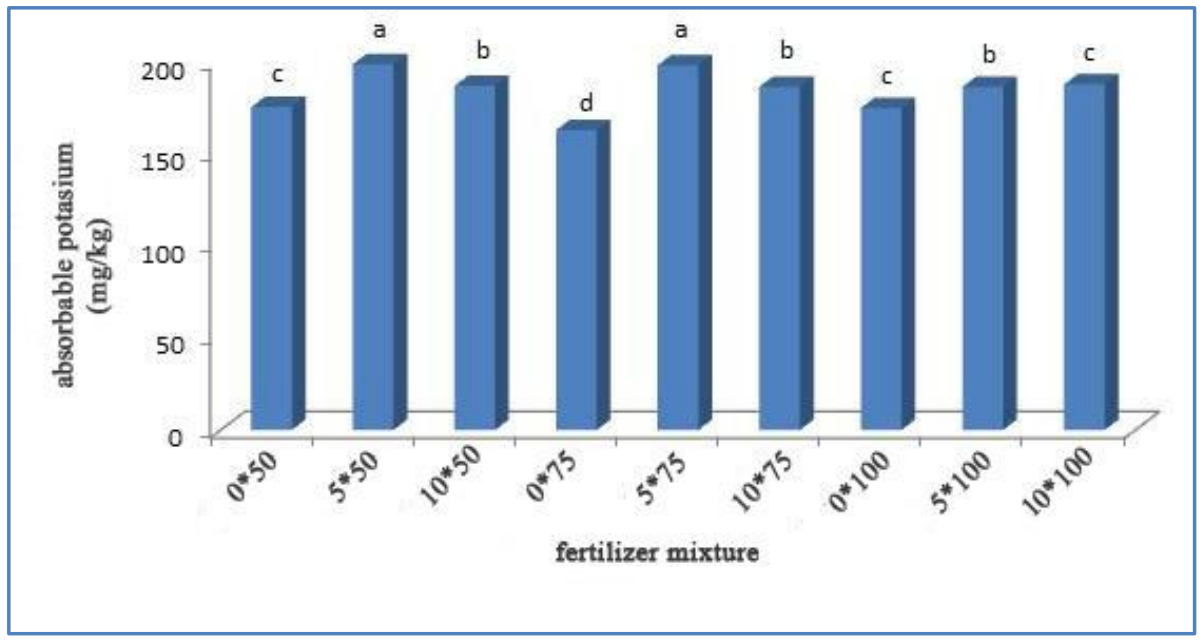

Figure 4 Mutual effect of vermicompost and nitrogen chemical fertilizer on absorbable potassium in soil. 
Results obtained from the average comparison of vermicompost effect on the soil potassium show that application of 5 tons/hectare of vermicompost has significant difference with the treatment of non-application of vermicompost, but increasing vermicompost up to 10 tons/hectare caused significant reduction in the soil potassium accumulation (table 2). This improvement was possibly due to the availability of high amount of potassium as organic compositions in the vermicompost which has been freed eventually. This eventual liberalization causes decrease in the discharge of this element by water (Mobser et al., 2006).

Combined application of vermicompost and nitrogen fertilizers showed limited effect on the level of absorbable potassium in soil and highest amount of absorbable potassium was reported from the treatment received the combination of 5 tons/ hectare and 10tones/hectare vermicompost along with $50 \mathrm{Kg} /$ hectare and $75 \mathrm{Kg} /$ hectare chemical nitrogen fertilizers respectively. According to Mobser et al. (2006) and Koocheki et al. (2008) increased amount of the vermicompost and chemical nitrogen fertilizers shows negative effect on the absorbable potassium level.

3.5 Effect of the fertilizers type and amount on the Bulk density

Results obtained from variance analysis show a significant effect of chemical nitrogen fertilizer and vermicompost treatment on the bulk gravity at the possible level of $1 \%$ while the combined application of these two shows non significant effect on the bulk gravity (table 1). Results of average comparison showed highest $\left(1.50 \mathrm{~g} / \mathrm{cm}^{3}\right)$ and lowest $\left(1.40 \mathrm{~g} / \mathrm{cm}^{3}\right)$ bulk gravity for the nitrogen treatments was reported from the treatment containing $50 \mathrm{Kg} /$ hectare and 100
$\mathrm{Kg} /$ hectare chemical nitrogen fertilizers. Similarly, for the vermicompost treatments, highest bulk gravity was reported from the treatments containing 10tons/hectare vermicompost (table 2). Result of interaction treatment shows that the most bulk gravity belong to the treatments in the use of nitrogen chemical fertilizers at the amount of $50 \mathrm{Kg} /$ hectare soil test and without the use of vermicompost fertilizer and also the least bulk gravity of soil belong to treatments of nitrogen chemical fertilizer at the amount of $100 \mathrm{Kg} /$ hectare of soil test and the use of vermicompost fertilizer at the amount of 10 tons/hectare. Similar types of results were observed by Nanjappa et al. (2001) and Jashankar \& Wahab (2004).

3.6 Effect of quantity of fertilizers and vermicompost on the actual density of soil

Results of variance analysis showed that the effect of chemical nitrogen fertilizer on the actual gravity at the possible level of $5 \%$ and the effect of vermicompost treatment at the possible level of $1 \%$ were meaningful (Table 1). Results of average comparison revealed that highest $\left(2.59 \mathrm{~g} / \mathrm{cm}^{3}\right)$ and lowest $\left(2.57 \mathrm{~g} / \mathrm{cm}^{3}\right)$ actual gravity from the treatment of chemical nitrogen application at the amount of $50 \mathrm{Kg} /$ hectare and 75 $\mathrm{Kg} /$ hectare respectively while the use of vermicompost fertilizer at the amount of 10 tons in hectare shows highest gravity (table 2). Analysis of results on interaction of treatments show that the highest actual gravity belong to the combined application of the $50 \mathrm{Kg} /$ hectare chemical nitrogen fertilizers without vermicompost fertilizer while the lowest actual gravity of soil belong to treatment of use of nitrogen fertilizers at the amount of $100 \mathrm{Kg} /$ hectare soil test and use of vermicompost at the amount of 10 tons/hectare. Results of the study are in agreement with the findings of Nanjappa et al. (2001) and Jashankar \& Wahab (2004).

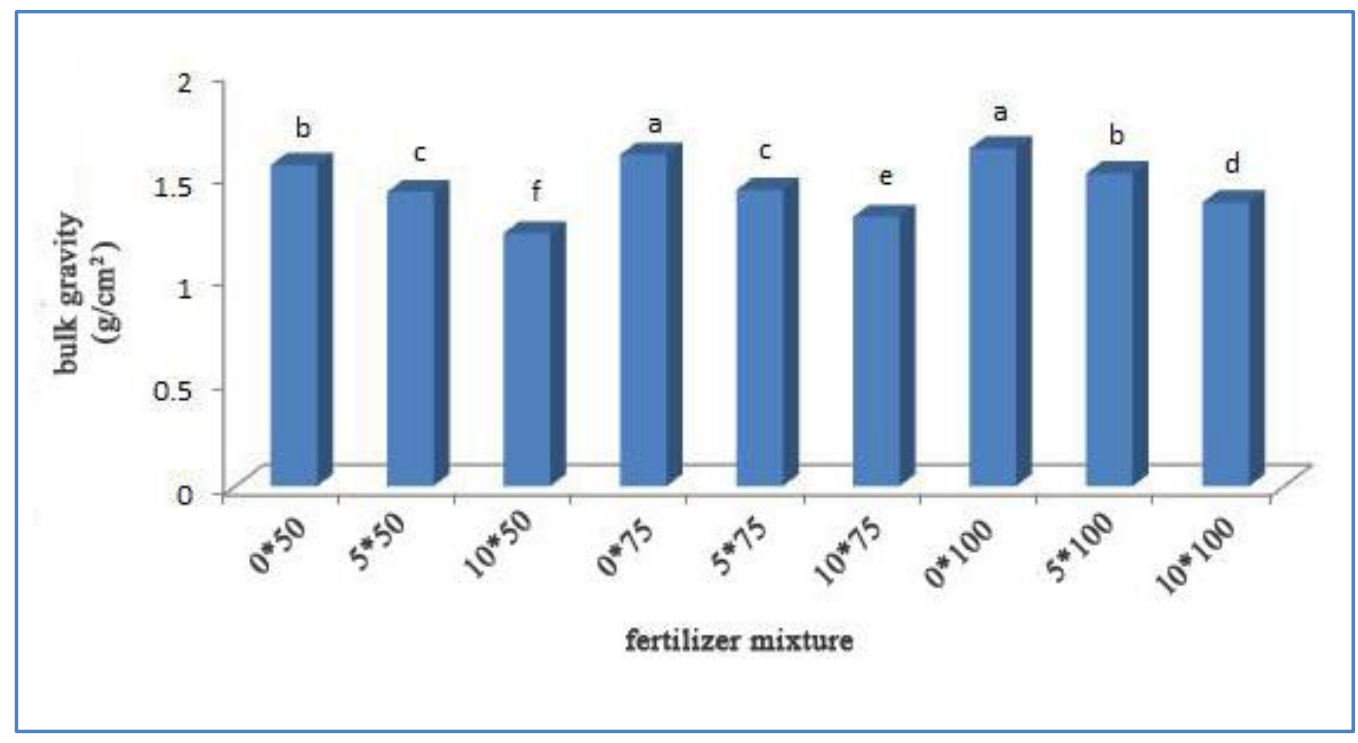

Diagram 5 the mutual effect of vermicompost and nitrogen chemical fertilizer on the bulk gravity 


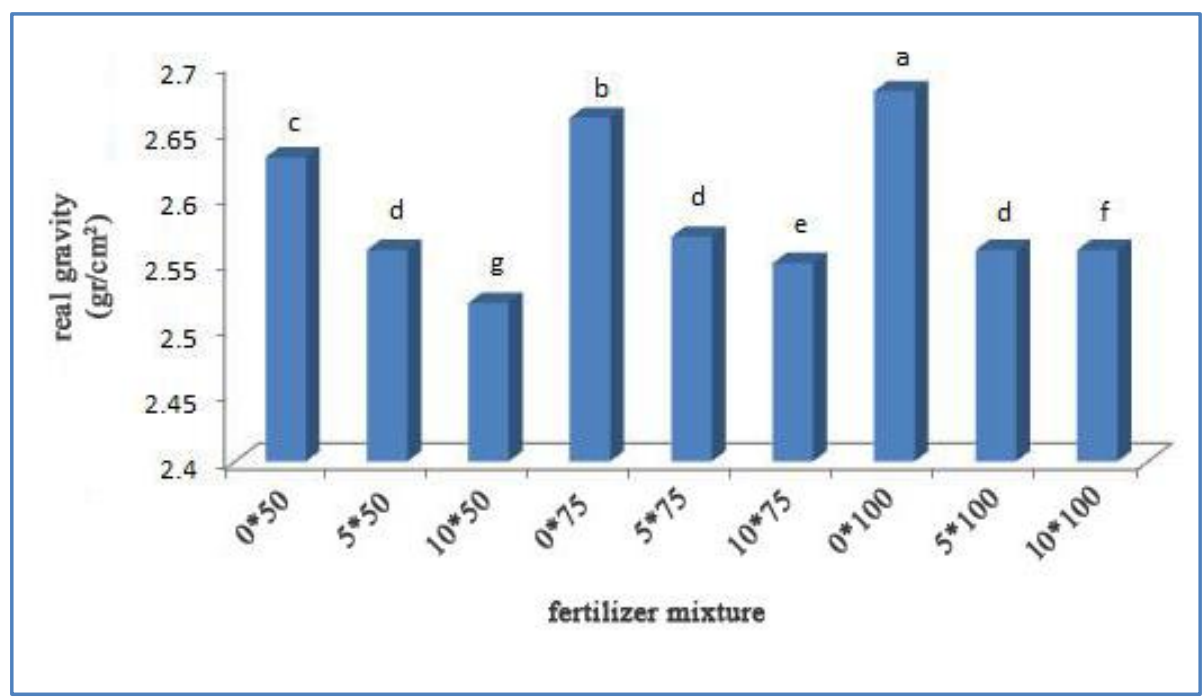

Figure 5 Combined effect of vermicompost and nitrogen chemical fertilizer on the real gravity

\section{Conclusion}

Consolidated determination of nutritious elements have been compensated with the use chemical and organic fertilizers and at the same time shortage of nutritious elements depend mainly on the soil fertility and maintenance and has the effect of production stability. Therefore with the application of organic fertilizers some the need of the corn plants for nitrogen is being met instead of using the chemical fertilizers. Results obtained from the study suggested that due to the eventual effect of application of organic and chemical fertilizers in this research in the multi duration test have been analyzed and again the result has been repeated with the change in the fertilizer treatments and the new results have been obtained.

\section{Conflict of interest}

Authors would hereby like to declare that there is no conflict of interests that could possibly arise.

\section{References}

Anwar M, Patra DD, Chand S, Kumar A, Naqvi AA, Khanuja SP S (2005) Effect of Organic Manures and Inorganic Fertilizer on Growth, Herb and Oil Yield, Nutrient Accumulation, and Oil Quality of French Basil. Communications in Soil Science and Plant Analysis 36: 1737-1746. doi:10.1081/CSS200062434

Arancon NQ, Edwards CA, Bierman P, Welch C, Metzger JD (2004) Influences of vermicomposts on field strawberries: 1. effects on growth and yields. Bioresource Technology 93: 145 153. doi:10.1016/j.biortech.2003.10.014.

Ayub M, Nadeem MA, Tanveer A, Husnain A (2002) Effect of different levels of nitrogen and harvesting times on growth, yield and quality of sorghum fodder. Asian Journal of Plant Science 1: 304-307.

Balyan JK, Puspendra S, Kumpawat BS, Jat ML (2008) Effect of organic manure, fertilizer level and biofertilizers on soil nutrients balance in maize (Zea mays L.). Research on Crops 9: 308-310.

Ehyaei MA, Behbehanizadeh A (1993) The soil analysis methods (Volume I). Soil and Water Research Institute, Publication No. 893, Tehran, Iran.

Galloway JN, Aber JD, Erisman JW, Seitzinger SP, Howarth RW, Cowling EB, Cosby BJ (2003) The nitrogen cascade. Bio Science 53:341-356.

Garg P, Gupta A, Satya S (2006) Vermicomposting of different types of waste using Eisenia foetida: A comparative study. Bioreso urce Technology 97:391-395. doi:10.1016/j.biortech.2005.03.009.

Hosseini Z (1994) Methods in food analysis. University Press, Shiraz University, Iran Pp 120.

Jashankar S, Wahab K (2004) Effect of integrated nutrient management on the growth, yield components and yield of Sesame. Sesame and Safflower Newsletter 20:602-608 available

on http://ecoport.org/ep?Search Type=earticleVie w\&earticleId=73 2\&page $=-2$ access on 20 April, 2015.

Khaliq A (2004) Irrigation and nitrogen management effects on productivity of hybrid sunflower (Helianthus annuus L.) PhD Thesis submitted to the Department of Agronomy, University of Agricultural Sciences, Faisalabad, Pakistan. 
Koocheki A, Jahan M, Nassiri Mahallati M (2008) Effects of arbuscular mycorrhizal fungi and free- living nitrogen fixing bacteria on growth characteristics of com (Zea mays L.). under organic and conventional cropping systems. Proceedings of the Second Scientific conference of the international Society of Organic Agriculture Research ISOFAR, held on June 18-20, 2008 at Modena, Italy Pp 336-339.

Kumar V, Singh KP (2001) Enriching vermicompost by nitrogen fixing and phosphate solubilizing bacteria. Bioresource Technology 76: 173-175. doi:10.1016/S09608524(00)00061-4.

Mobser HR, Heidari Sharif Abad H, Mousavi Nik SM, Noor Mohammadi GH, Darvish F (2006) Study the effect of potassium, zinc, and copper enrichment of wheat seed yield and water shortage conditions. Journal of Agricultural Sciences $4: 133-143$.

Mojiery A, Arzani A (2003) Effect of different levels of nitrogen fertilizer and bushes density on its functioning and components in sunflower. Journal of Science \& Agricultural and Natural Resources 7: 115-125.

Nanjappa HV, Ramachandrappa BK, Mallikarjuna BO (2001) Effect of integrated nutrient management on yield and nutrient balance in maize (Zea mays L.). Indian Journal of Agronomy 46: 698-701.

Pramanik P, Ghosh GK, Ghosal PK, Banik P (2007) Changes in organic $-\mathrm{C}, \mathrm{N}, \mathrm{P}$ and $\mathrm{K}$ and enzyme activities in vermicompost of biodegradable organic wastes under liming and microbial inoculants. Bioresource Technology 98 : 24852494. doi:10.1016/j.biortech.2006.09.017

Rejali F, Khavazi K (2001) Soil worm and their role in the increase of soil fertility.Proceedings of industrial production necessity of biological fertilizers in the country. 547-557

Riggy MR (2003) Greenhouse study of 3 types of vermicompost and nitrogen fertilizer on the functioning of chemical mixture of corn and rice plants. M. Sc. Thesis submitted to Shiraz University, Iran Pp146.

Roesty D, Gaur R, Johri BN, Imfelda G, Sharmab S, Kawaljeetb K, Aragno M (2006) Plant growth stage, fertiliser management and bio-inoculation of arbuscular mycorrhizal fungi and plant growth promoting rhizobacteria affect the rhizobacterial community structure in rain-fed wheat fields. Soil Biology and Biochemistry 38: 1111-1120. doi:10.1016/j.soilbio.2005.09.010

Rosenstock TS, Liptzin D, Six J, Tomich TP (2013) Nitrogen fertilizer use in California: Assessing the data, trends and a way forward. California Agriculture 67: 68-79. doi: 10.3733/ca.E.v067n01p68.

Savci S (2012) An Agricultural Pollutant: Chemical Fertilizer. International Journal of Environmental Science and Development 3:77-80. 